\begin{tabular}{ll} 
PAREZJA 1/2015(3) & DOI: $10.15290 /$ parezja.2015.03.13 \\
\hline ISSN 2353/7914 & POD PREGGIERZEM ŚMIECHU
\end{tabular}

Sylwia Jaskulska

Uniwersytet im. Adama Mickiewicza w Poznaniu

E-MAIL: jaskulsk@amu.edu.pl

Karol Motyl

Akademia im. Jana Długosza w Częstochowie

E-MAIL: k.motyl@ajd.czest.pl

\title{
Chodź ucieknijmy..., czyli rzecz o akademickim nieposłuszeństwie
}

\section{STRESZCZENIE}

Celem tekstu jest ukazanie problemów związanych z procesem przemian w szkolnictwie wyższym, szczególnie z parametryzacją, której przedmiotem staje się naukowy dorobek akademików. Wśród dających się zaobserwować reakcji środowiska na tę sytuację, godną uwagi jest postawa, którą na wzór terminu „obywatelskie nieposłuszeństwo" autorzy tekstu nazywają nieposłuszeństwem akademickim. Przywołane w tekście przykłady dotyczą działań, które są wyrazem niegodzenia się z rzeczywistością i szukania dróg jej zmiany, co - w myśl wniosków, do których dochodzą autorzy - jest przywilejem i obowiązkiem naukowców.

SŁOWA KLUCzowE: szkolnictwo wyższe, parametryzacja, nieposłuszeństwo obywatelskie.

[...] nie musimy stuchać innych [...] Chodź ucieknijmy stąd, nikt nie będzie mówit nam co dla nas jest najlepsze $[\ldots]^{1}$

Kamil Bednarek

Pisząc o akademickim nieposłuszeństwie, damy mu wyraz już na wstępie, formułując cele tego tekstu, czy może raczej tworząc listę celów, które mu nie przyświecają. Nie chcemy więc ani wyczerpująco charakteryzować kategorii nieposłuszeństwa obywatelskiego (choć jest ona teoretyczną ramą naszych rozważań i na pewno zostanie w jakimś stopniu zarysowana), ani opisywać tego zjawiska. W artykule nie prezentujemy wyników naszych badań zgodnie

Fragment tekstu piosenki Kamila Bednarka Chodź ucieknijmy..., pochodzącej z debiutanckiego studyjnego albumu wokalisty zatytułowanego Jestem.... (2012). 
ze standardami APA. Mottem nie jest wzniosły cytat $\mathrm{z}$ klasyka, ale fragment tekstu popularnej piosenki. Nie ma dla nas znaczenia, jaka będzie objętość tego tekstu i nie piszemy go po to, żeby uzyskać punkty czy zwiększyć nasz h-index. Po co więc jest ta wypowiedź? Celem jest przedstawienie naszych rozważań na temat współczesnych przemian w polskiej nauce, a w szczególności w humanistyce oraz - będącego ich konsekwencją - sprzeciwu akademików.

Tekst być może przybierze formę swobodnej narracji, niejako sprawozdania z naszych umysłów. Tak byśmy chcieli. Ale w trakcie pisania jego charakter może się zmienić. Istnieje także cel „wewnętrzny” - jest nim zaspokojenie naszych potrzeb emocjonalnych, ponieważ pisanie tego artykułu daje nam wiele radości, satysfakcji oraz w pewnym sensie poczucie spełnienia naukowego. Czujemy się w tym nieposłuszeństwie wolni, swobodni, nieskrępowani. Piszemy na naszych zasadach, o tym, co chcemy i jak chcemy. Jednak z szacunkiem dla pisma, które zaprosiło nas na swoje łamy i dla czytelników, którzy po ten tekst zechcą ewentualnie sięgnąć. Zacznijmy zatem jeszcze raz.

Skąd fragment piosenki Kamila Bednarka Chodź ucieknijmy, motto naszego tekstu? Chyba każdy z nas czuje czasem potrzebę ucieczki. Ucieczki gdzieś, od czegoś. Różnie tę potrzebę realizujemy. Niekoniecznie, przywołując inną piosenkę, wsiadamy do byle jakiego pociągu. Czasem zostaje ona tylko jako myśl w głowie czy uczucie w sercu, czasem uciekamy do własnego świata, do wnętrza siebie. Bywa i tak, że, paradoksalnie, ta potrzeba ucieczki prowokuje nas do działań (np. robienia czegoś na przekór). Przeciwstawiamy się czemuś, z czymś walczymy, zabiegamy o coś, co staje się dla nas ważne, bo jest kontrapunktem tego, co potrzebę ucieczki wywołało. Jednym z przykładów takich działań mogą być też przejawy nieposłuszeństwa.

W naszym tekście skupiamy się na uwikłaniach związanych szczególnie z procesami parametryzacji, których podmiotami są jednostki naukowe, a pośrednio akademicy i o dyskretnej, subtelnej potrzebie ucieczki (może to nawet zbyt mocne słowa) i nieposłuszeństwa, które rozumiemy jako postawę obywatelską, sposób niegodzenia się z rzeczywistością, drogę jej zmieniania.

Nieposłuszeństwo obywatelskie definiowane jest jako „publiczny akt łamania przepisu prawa lub nakazu władzy stanowiący protest przeciwko niesprawiedliwości. Można także termin ten rozumieć jako rodzaj moralnego apelu, którego celem jest naświetlenie powagi problemu i doprowadzenie do otwartej debaty publicznej, w wyniku której niesprawiedliwe prawo mogłoby zostać zmienione”. John Rawls formułuje definicję tego terminu: „jako

\footnotetext{
A. Szutta, Przemoc a obywatelskie nieposłuszeństwo, „Analiza i Egzystencja” 2013, nr 22, s. 171.
} 
czynu publicznego, dokonanego bez użycia przemocy, dyktowanego sumieniem aczkolwiek politycznego, sprzecznego z prawem, zwykle mającego na celu doprowadzenie do zmiany prawa bądź kierunków polityki rządu"3. Co ważne, osoby podejmujące działania, które można określić aktami obywatelskiego nieposłuszeństwa, liczą się z możliwością, że zostaną za nie ukarane. Czasem wręcz się na karę wystawiają, bo poddanie się jej także jest formą manifestacji własnych poglądów. Nieposłuszeństwo obywatelskie tym różni się od przestępstw czy wykroczeń, że nie wiąże się z rozwiązaniami siłowymi, z przemocą, z agresją. Nie są to też działania w ukryciu, ale jawne, dzieją się na oczach ludzi, których dotyczą. Zwykle też dopuszczające się ich osoby nie działają tylko we własnym interesie, chcą zadbać o sprawy grupy, którą reprezentują.

Nieposłuszeństwo obywatelskie osób pracujących w jednostkach naukowych postanowiliśmy nazwać nieposłuszeństwem akademickim. Jak pisze Henry Giroux, „edukacja wyższa pełniła zawsze - choć w zniekształconych formach - funkcję symbolicznego i konkretnego napomnienia, definiującego walkę o demokrację jako - w pewnym sensie - usiłowanie wyzwalania ludzkości z pęt ślepego posłuszeństwa wobec władzy”». Akademickie nieposłuszeństwo rozumiemy jako formę aktywności akademickiej polegającą na publicznym działaniu (albo zaniechaniu działania), które ma na celu albo demonstracyjne złamanie nakazu władzy, albo obnażenie pozoru przez jego ujawnienie, wyśmianie. Służy manifestacji odrębnego stanowiska i wyrażeniu sprzeciwu wobec niesprawiedliwości czy szkodliwości pewnych zjawisk. Akademickie nieposłuszeństwo raczej wyrażane jest przez apel naświetlający jakiś problem niż publiczny akt łamania prawa. Taka aktywność, podejmowana przede wszystkim w obronie podstawowej idei i misji uniwersytetu i na rzecz wyższych wartości, odbywa się bez użycia przemocy, czasem nawet jedynie symbolicznie. Aby móc kontynuować nasze rozważania, musimy odpowiedzieć na pytanie, co jest (co może być) narzędziem akademickiego nieposłuszeństwa?

Środowisko akademickie, społeczność badaczy, myślicieli, odkrywców, to powinni być ludzie, którzy nie kierują się zasadami konformizmu myślowego. W swojej działalności zadają pytania, podważają, poszukują nowego

3 J. Rawls, Teoria sprawiedliwości, przekł. M. Panufnik, J. Pasek, A. Romaniuk, Wydawnictwo Naukowe PWN, Warszawa 1994, s. 500.

4 H. A. Giroux, Naga pedagogia i przekleństwo neoliberalizmu: przemyśleć edukację wyższa jako praktykę wolności, przekł. P. Zamojski, [w:] H. Giroux, L. Witkowski, Edukacja i sfera publiczna. Idee i doświadczenia pedagogiki radykalnej, Oficyna Wydawnicza Impuls, Kraków 2010, s. 289. 
albo w starym dostrzegają nowe rozwiązania. Pytają o zasadność zastanej rzeczywistości, kwestionują przyjęte przez ogół sposoby myślenia i działania, niejednokrotnie łączą, zestawiając czy porównując ze sobą idee, kategorie czy teorie na pierwszy rzut oka niemające ze sobą nic wspólnego. Osoby, które $\mathrm{w}$ ten sposób uprawiają naukę zapewne napotkają krytykę. Jest ona i szansą (daje możliwość weryfikacji tez i twierdzeń), i zagrożeniem, jeśli przybiera postać destrukcyjnego w skutkach krytykanctwa. Trafnie ujęła to Hannah Arendt pisząc, że w czasach, kiedy większość społeczeństwa bezmyślnie podąża za tym, co robią i w co wierzą wszyscy, za tym, co z góry narzucone i bezrefleksyjnie uznane przez ogół za dobre, pożyteczne czy rozwojowe, to właśnie indywidualiści, generujący wiatr myślenia, są wyciągani ze swoich kryjówek i narażeni na krytykę ogółu5. Odmowa uczestnictwa w powszechności, czyli postawa z pozoru nacechowana biernością, staje się rodzajem działania wyrażającego sprzeciw. Nie stałoby się to możliwe, gdyby nie przywołany wcześniej wiatr myślenia, pewien konstruktywny ferment intelektualny, swoiste umysłowe nieposłuszeństwo, które wywiera istotny wpływ na wszystkie ustalone kryteria, wartości, miary dobra i zła, jednym słowem na wszystkie zwyczaje i reguły działania ${ }^{6}$. Inaczej mówiąc, proces myślenia według H. Arendt, pozwala człowiekowi burzyć schematy i podważać istniejące reguły. Taka zdolność oddzielania dobra od zła, piękna od brzydoty, w chwilach krytycznych może ustrzec przed katastrofą, ponieważ myślenie budzi ze snu?. Jak pisze, z charakterystyczną ironią, Wisława Szymborska: „Nie ma rozpusty gorszej niż myślenie./Pleni się ta swawola jak wiatropylny

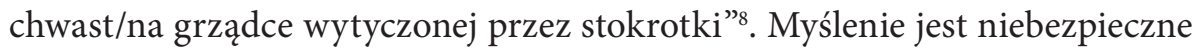
tylko z pozoru i tylko dla pozoru - nie zagraża ono prawdzie. Nie zagraża człowiekowi. Zagraża tylko działaniom pozornym, które pod płaszczykiem najwyższych wartości są szkodliwe i niebezpieczne9.

Akademicy są wyposażeni w narzędzia intelektualne, które pozwalają im szukać inspiracji poznawczych i światopoglądowych, także w tych przekonaniach i kategoriach, które przez naukowy mainstream są traktowane $\mathrm{z}$ nieufnością i podejrzliwością czy ignorancją ${ }^{10}$. Pozwalają one także na dokona-

$5 \quad$ H. Arendt, Myślenie, przekł. H. Buczyńska-Garewicz, Wydawnictwo Czytelnik, Warszawa 2002 , s. $257-258$.

6 E. Barańska, Moralność w polityce: rozważania w kontekście teorii politycznej Hannah Arendt, „Teki Komisji Politologii i Stosunków Międzynarodowych - OL PAN” 2008, s. 49.

H. Arendt, Myślenie, s. 257-258.

W. Szymborska, Wiersze wybrane, Wydawnictwo a5, Kraków 2004, s. 271.

H. Arendt, Myślenie, s. 257-258.

10 M. Czyżewski, Dyskursy tożsamościowe w nauce i życiu społecznym: odmiany, własności, funkcje, [w:] Tożsamość, nowoczesność, stereotypy. Księga Jubileuszowa poświęcona Profe- 
nie krytycznej refleksji odnośnie przemian współczesnego świata, a przede wszystkim (co dla pracowników nauki powinno być szczególnie istotne) przemian w obrębie nauki i szkolnictwa wyższego. Jak pisze Maria Czerepaniak-Walczak, Polska jest szczególnym przypadkiem kraju europejskiego, w którym zatwierdzane są wszystkie programy kształcenia akademickiego na podstawie zgodności z centralnymi zarządzeniami ${ }^{11}$. Krajowe Ramy Kwalifikacji (których wprowadzenie winnych krajach Starego Kontynentu poprzedzały liczne idługotrwałe dyskusje, przygotowania oraz badania) ${ }^{12}$, z narzędzi poprawy jakości kształcenia na polskich uczelniach stały się celem samym w sobie, banalizowane i trywializowane przez niektórych, przez innych traktowane jako jedyny trafny klucz do projektowania działań edukacyjnych. Można powiedzieć, że odwróciły uwagę od spraw istotnych, na rzecz biurokracji i uniformizowania kształcenia.

W pewnym sensie nasz kraj dryfuje na wodach głównego nurtu reform uniwersytetu europejskiego, których cele na poziomie systemowym zdają się być czysto utylitarne: językiem efektów kształcenia opisuje się miejsce studentów na rynku pracy i ich społeczną przydatność. Maria Dudzikowa w jednym z wątków eseju NieKOMFORTOWE POŁȮ̇enIE INSTYTUCJI UNIWERSYTETU W KŁOPOTLIWYM KONTEKŚCIE.... podnosi problem napięcia między dwoma pełnionymi przez uniwersytety rolami: pierwsza $\mathrm{z}$ nich to napędzanie rozwoju ekonomicznego kraju, druga, rozwoju społecznego ${ }^{13}$. Rodzi to napięcie, bo uczelnie mają pełnić jednocześnie role, które w pewnym sensie nawet się wykluczają. Dryfować więc nie zawsze znaczy płynąć! Analizując proces poddawania się przez uniwersytety presji rynku można odnieść wrażenie, że nie zmierzamy świadomie do wcześniej wyznaczonej przystani, tylko dajemy się ponieść bezwładnie, bez nawigatora, bez masztu i żagli w bliżej nieoznaczone miejsce. Jakie? Możliwe, że do cichej i bezpiecznej zatoki lub dobrze prosperującego portu. Możliwe jednak, że osiądziemy na mieliźnie lub, co gorsza, rozbijemy się o skały. Nie dziwi więc, że pojawia się

sorowi Zbigniewowi Bokszańskiemu, R. Dopierała, K. Kaźmierska (red.), Nomos, Kraków 2012, s. 101-120.

${ }_{11}$ M. Czerepaniak-Walczak, Autonomia w kolorze sepii w inkrustowanej ramie KRK. O procedurach i treściach zmiany w edukacji akademickiej, [w:] Fabryki dyplomów czy universitas? O „nadwiślańskiej” wersji przemian w edukacji akademickiej, M. Czerepaniak-Walczak (red.), Oficyna Wydawnicza Impuls, Kraków 2013, s. 37.

12 Ibidem, s. 56.

13 M. Dudzikowa, Niekomfortowe położenie instytucji uniwersytetu w kłopotliwym kontekście. Esej w trosce o rozwój (nie tylko) kapitału społecznego, [w:] Oblicza kapitału społecznego uniwersytetu. Diagnozy - interpretacje - konteksty, M. Dudzikowa, R. Wawrzyniak-Beszterda, S. Jaskulska, M. Marciniak, E. Bochno, I. Bochno, K. Knasiecka-Falbierska, Oficyna Wydawnicza Impuls, Kraków 2013, s. 306 i nast. 
potrzeba nieposłuszeństwa wobec mainstreamowych przemian, schematów, procesów, w których ujawnia się zagubiona w pogoni za konstrukcją różnych, jak nazywa je Zbigniew Król, „bolońskich” i „lizbońskich” gadżetów funkcja nauki - tłumaczenie i wyjaśnianie świata połączone $z$ dążeniem do jego zrozumienia i przekształcania ${ }^{14}$.

Po opisaniu, jak rozumiemy akademickie nieposłuszeństwo oraz czym może być ono uwarunkowane, chcieliśmy zastanowić się, jakie są potencjalne płaszczyzny, w których może się ono manifestować.

Pierwszą płaszczyzną może stać się działalność dydaktyczna. Nauczyciel akademicki może, o ile i na ile to możliwe, edukować studentów zgodnie $\mathrm{z}$ tradycyjnym, Humboldtowskim modelem uniwersytetu, zapewniając im wszechstronne wykształcenie akademickie i nie gubiąc „ducha akademickiego" (rozumiemy go jako budowanie wspólnot problematyzujących rzeczywistość, stawiających pytania, poszukujących odpowiedzi). Nieposłuszeństwo akademickie może być wyrażane także - i to druga z płaszczyzn - przez działalność organizacyjną, w ramach której akademicy mogą organizować konferencje naukowe, sympozja lub seminaria na temat problemów współczesnej nauki i szkolnictwa wyższego, owocem których mogą stać się krytyczne opracowania naukowe, wystosowanie listu otwartego do odpowiednich władz lub uzgodnienie wspólnego stanowiska lub strategii działania.

Nauczyciele akademiccy mają wszak do dyspozycji jedno z najpotężniejszych narzędzi, jakim jest słowo w jego formie mówionej i pisanej. Swój sprzeciw wobec przemian w nauce można manifestować udziałem w tych konferencjach naukowych, debatach czy panelach dyskusyjnych, które mogą stać się forum do przedstawienia swojego stanowiska na temat współczesnych tendencji w polskiej nauce. Akademickie nieposłuszeństwo może być także wyrażone w treści artykułów, w projektach badań nad stanem nauki i sporządzonych w ich ramach raportach, krytycznych analizach czy esejach. Kolejną płaszczyzną wyrażania własnych poglądów może być zatem działalność naukowa.

Nieposłuszeństwo obywatelskie jest przede wszystkim formą adresu, apelu mieszczącego się w ramach dialogu obywatelskiego. Będąc formą apelu, obywatelskie nieposłuszeństwo, ze swojej definicji, jest odwoływaniem się do racji rozumowych bądź argumentów moralnych, jest próbą nawiązania dialogu, przekonania drugiej strony, aby zmieniła swoją niesprawiedliwą decyzję̧${ }^{15}$.

${ }_{14}$ Z. Król, Filozofia a nauki ścisłe, „Filozofia i Nauka. Studia Filozoficzne i Interdyscyplinarne", t. 2, 2014, s. 66-67.

15 A. Szutta, Przemoc a obywatelskie..., s. 180. 
Dyskurs akademicki wokół przemian szkolnictwa wyższego i ich negatywnego wymiaru wpisuje się w koncepcję „wspólnego namysłu”, czyli demokracji deliberatywnej ${ }^{16}$. Jej idea zasadza się na uznaniu prawa ludzi do wyrażania siebie i argumentowania, ustalania prawa w dyskusjach, debatach. W obliczu zjawisk, które uznajemy za niegodziwe, niesprawiedliwe, wobec nieprzemyślanych działań innych ludzi, możemy zabierać głos. Tej formie demokracji, zwanej także bezpośrednią, przyświeca przekonanie, że decyzje polityczne mogą być wypracowywane w dużym stopniu przez obywateli, a konsensus osiągany jest $\mathrm{w}$ debatach, podczas których są prezentowane i uzasadniane różne stanowiska ${ }^{17}$. Choć mówi się o zagrożeniach demokracji deliberatywnej, jak choćby o niebezpieczeństwie polaryzacji stanowisk (dyskusja publiczna prowadzi do radykalizacji stanowisk wyjściowych), debatowanie, zgłaszanie zastrzeżeń, publikowanie krytyki, argumentowanie to działania, które podjąć można i podejmować należy. W czasach, gdy życie częściowo przenosi się do Internetu, przejawem zaangażowania obywatelskiego może być także prowadzenie blogów, aktywność na forach internetowych, na portalach społecznościowych. Jako forum wymiany myśli pedagogicznej postrzegamy czasopisma takie, jak „Parezja”, fenomen „Międzyszkolnika”"18 czy blogów prowadzonych przez pedagogów, np. przez Profesora Bogusława Śliwerskiego ${ }^{19}$. Służą one z pewnością „demokratyzacji życia społecznego, zwiększaniu efektywności wpływu obywateli na państwo, poszerzenie zakresu spraw podlegających współrozstrzyganiu"º, zatem są przejawem, jak nazywa go Robert Goodin, interpersonalnego aspektu deliberacji ${ }^{21}$. Można pokusić się w tym miejscu o przywołanie hasła "demokracja performatywna”, którą Elżbieta Matynia rozumie jako kategorię pozwalającą dostrzec pozaproceduralny wymiar demokracji, wymagającej rzeczywistych działań obywateli ${ }^{22}$. Demo-

J. Reykowski, Procesy grupowe a rozwiazywanie antagonistycznych konfliktów: Czy idea demokracji deliberatywnej może mieć swój psychologiczny sens?, „Psychologia Społeczna”, 2007, t. 2, s. 99.

17 J. Wasilewski, Podstawy demokracji deliberatywnej, [w:] Konflikt i porozumienie. Psychologiczne podstawy demokracji deliberatywnej, J. Reykowski (red.), Wydawnictwo Szkoły Wyższej Psychologii Społecznej „Academica”, Warszawa 2007, s. 14.

18 „Międzyszkolnik” to ogólnopolskie pismo internetowe Forum Młodych Pedagogów. Jego celem jest podtrzymywanie kontaktów oraz wymiana informacji między uczestnikami Letnich Szkół Młodych Pedagogów.

19 http://sliwerski-pedagog.blogspot.com [10.12.2014].

${ }^{20}$ A. Jakubiak-Mirończuk, Model tworzenia prawa w Polsce po reformie Better Regulation a idea demokracji deliberatywnej, „Zeszyty Naukowe Zakładu Europeistyki Wyższej Szkoły Informatyki i Zarządzania w Rzeszowie” 2009, nr 3, s. 6.

${ }^{21}$ J. Wasilewski, Podstawy demokracji..., s. 16.

22 E. Matynia, Negocjujmy rewolucje: uwagi o demokracji performatywnej, „Kultura i Edukacja” 2009, nr 2 (71), s. 150. 
kracja performatywna bowiem, ,jest projektem stawiającym wyzwanie kulturze niesprawiedliwości przez powoływanie do życia przestrzeni publicznej, w której ludzie budują alternatywy dla przemocy i rozpaczy"23.

Uspołecznianie demokracji, czyli zachęcanie ludzi do działań grupowych, nie zaś tylko indywidualnych, jest jednym z postulatów demokracji deliberatywnej. Fenomen blogów czy grup internetowych, szczególnie, jeśli skupiają ludzi, których łączy coś jeszcze poza samą wymianą myśli w Internecie (jak np. „Międzyszkolnik” łączy uczestników Letnich Szkół Młodych Pedagogów $\left.{ }^{24}\right)$, daje znakomitą ku temu okazję.

Dłużej zatrzymamy się też na subtelnej (ale czytelnej) krytyce obecnego systemu znajdującej odzwierciedlenie w formach kabaretowych, komedii, pastiszu. Jak pisze Maria Dudzikowa, śmiech daje katartyczną przyjemność nadużycia tabu, zapobiega poczuciu alienacji, rozładowuje agresję i ułatwia radzenie sobie $\mathrm{z}$ trudnościami ${ }^{25}$. Humor wyzwala myślenie niekonwencjonalne i zwiększa elastyczność w wartościowaniu i ocenie konkretnych zjawisk. Śmiech ma także zdolności humanizowania życia, odnowy zbiorowej podmiotowości i przypisywania indywidualnej tożsamości. Spełnia on również funkcje i zadania emancypacyjne, ponieważ pozwala wyrażać kulturowy opór i krytykę.

W tym miejscu chcielibyśmy przywołać zdarzenie, które jest główną inspiracją tego tekstu. Chodzi o nasz występ podczas XXVIII Letniej Szkoły Młodych Pedagogów, zorganizowanej w Sandomierzu 15-20 września 2014 roku. Jednym z wieloletnich rytuałów podczas tego wydarzenia jest konieczność wykupienia dyplomów uczestnictwa podczas ostatniej, uroczystej kolacji. Można to zrobić na wiele sposobów - recytując wiersz, grając na instrumencie. Liczy się kreatywność i poczucie humoru, całe zaś wydarzenie ma walory integracyjne. Jest też pewną formą podsumowania Szkoły, która ze względu na swój charakter znacznie różni się od większości konferencji naukowych. W tym roku zaśpiewaliśmy piosenkę zespołu Clean Bandit Rather BE. Pozwoliliśmy sobie wyświetlić na ekranie znajdującym się za nami naszą wersję „tłumaczenia” tekstu tego utworu. Zawierała ona (potraktowany z przymrużeniem oka) opis dylematów młodego badacza. Poruszyliśmy takie prob-

${ }^{23}$ E. Matynia, Demokracja performatywna, „Alternativa Dictionery”, http://alternativa.org. $\mathrm{pl} /$ dictionary/? $\mathrm{p}=104$ [13.03.2014].

24 Letnia Szkoła Młodych Pedagogów jest corocznym spotkaniem młodych adeptów nauki z Mistrzami pedagogiki. Organizowana jest przez Komitet Nauk Pedagogicznych PAN. Jej wieloletnim kierownikiem naukowym jest prof. zw. dr hab. Maria Dudzikowa.

25 M. Dudzikowa, Poczucie humoru nauczycieli w ocenie uczniów, [w:] Problemy wspótczesnej pedeutologii. Teoria-praktyka-perspektywy, D. Ekiert-Oldroyd (red.), Wydawnictwo Uniwersytetu Śląskiego, Katowice 2003, s. 109. 
lemy, jak pogoń za liczbą cytowań, uprzywilejowaną pozycję indeksu Hirscha i wskaźnika Impact Factor w ocenie pracowników nauki i czasopism naukowych, trudny dostęp do pism „prestiżowych”. Odnieśliśmy się także do traktowania młodych, aczkolwiek prężnie rozwijających się czasopism naukowych jako periodyków bez perspektyw, a nowatorskich, ambitnych i dobrze napisanych artykułów publikowanych w mało znanych i nisko punktowanych czasopismach jako tekstów drugiej kategorii. Przede wszystkim chcieliśmy wyrazić nasze zaniepokojenie tzw. polityką punktową w nauce. Przez wyśmianie tendencji obecnych we współczesnym życiu naukowym zamanifestowaliśmy... nasze akademickie nieposłuszeństwo? Pewnie tak, przynajmniej w jakimś stopniu. Spotkało się to z przyjazną reakcją naszych Koleżanek i Kolegów - uczestników Letniej Szkoły. Coś, co było początkowo zabawą, stało się dla nas pretekstem do głębszej refleksji, przyczynkiem wielu rozmów, które prowadziliśmy z różnymi osobami po Letniej Szkole. Nadal docierają do nas oznaki sympatii, ale także słowa krytyki. Świadomie dotknęliśmy tematu, który polaryzuje poglądy, stanowiska i wzbudza emocje. Nie spodziewaliśmy się jednak, że przyjdzie nam zmierzyć się z tak różnymi reakcjami ludzi, których dotyczą poruszane przez nas kwestie. Nie żałujemy, chętnie rozmawiamy, sami mamy teraz więcej przemyśleń i (chyba możemy to powiedzieć) czujemy się w jakiś sposób ubogaceni. I tak oto forma kabaretowa, pastisz akademickiej rzeczywistości stał się czymś więcej... W kabarecie wiele można. Autorzy kabaretowi poruszają się na granicy tego, co dozwolone i tego, co zakazane, tego, co poprawne i tego, co może bulwersować. Jeśli robią to w imię jakiejś idei, chyba można mówić o rodzaju obywatelskiego nieposłuszeństwa. Naturalnie zdajemy sobie sprawę, zarówno my, jaki i zapewne nasi koledzy z Kabaretu LSMP ${ }^{26}$ (a jest to kabaret w naszej ocenie genialny zarówno w płaszczyźnie pisanych przez uczestników Szkół tekstów, jak i wykonania), że nie mamy akurat przez te, artystyczne działania, wielkich zasług w zmienianiu akademickiej rzeczywistości. Na pewno też nie przypisujemy sobie działań wywrotowych czy na granicy prawa, lecz publiczne zabieranie głosu to „nie takie znowu nic”, jak w jednej ze swoich piosenek śpiewa Grzegorz Turnau

26 Kabaret „Behe-co” jest tradycją Letnich Szkół Młodych Pedagogów. Co roku uczestnicy przygotowują i wystawiają autorski spektakl, zwykle komentujący rzeczywistość edukacyjną. Obok walorów satyrycznych ma on także wartość dydaktyczną. Por. U. Bylica, B. Dąbrowski, Od Gali do Kabaretu - programy satyryczne Letnich Szkół Młodych Pedagogów, [w:] O budowaniu kapitału ludzkiego i społecznego w środowisku naukowym. 2o-lecie Letniej Szkoły Młodych Pedagogów przy Komitecie Nauk Pedagogicznych PAN, E. Bochno, A. Korzeniecka-Bondar (red.), Wydawnictwo Uniwersytetu Marii Curie-Skłodowskiej, Lublin 2011. 
Abstrahując już od naszego występu, a wracając do głównych tez tego tekstu: wydaje nam się, że najlepszym sprzeciwem naukowca wobec współczesnych przemian w nauce są działania, które określamy postępowaniem „pod prąd”, zgodnym ze swoimi przekonaniami, umożliwiającym rozwój i samoaktualizację drzemiących w badaczu potencjału i możliwości, które mogą przyczynić się do rozwoju określonej dziedziny nauki, a akademikowi dać poczucie spełnienia i dobrze wykonanego zadania. Wymaga to odwagi i poświęceń. Byliśmy świadkami, jak nasi Mistrzowie odrzucali intratne (przynoszące wymierne korzyści finansowe) propozycje, bo nie mieściły się one w ramach uznawanych przez nich standardów. Co roku obserwujemy Profesorów, którzy bezinteresownie poświęcają swój czas i służą radą i mądrością uczestnikom Letnich Szkół Młodych Pedagogów. To jest dla nas uniwersytet w najczystszej postaci. Mamy dużo szczęścia, że tego doświadczamy. Spotykamy też na naukowej drodze ludzi, zwykle młodych, zrezygnowanych, wycofujących się, sceptycznych. Wolą oni zrezygnować niż płynąć z nurtem przemian, których nie akceptują. Niektórzy są na etapie ostentacyjnego zaniechania bierność, „nicnierobienie” to też przejawy obywatelskiego nieposłuszeństwa. Ale stagnacja, nawet w słuszne imię nie pozwala się rozwijać.

Uprawianie dziś nauki to poruszanie między dwiema ścierającymi się w polskim szkolnictwie wyższym orientacjami. Za M. Czerepaniak-Walczak, która kwestie te opisuje w odniesieniu do kształcenia w Polsce doktorantów, można powtórzyć:

Orientacja na naukę wyraża się w nastawieniu na osiąganie takich efektów edukacji [...], które wyrażają się w stawianiu nowych pytań, odkrywaniu nowych terytoriów poznania oraz stawianiu ryzykownych hipotez, doświadczaniu niepewności i radości odkrywania. Orientacja na rynek zaś wyraża się w kształtowaniu kompetencji wymaganych do rozwiązywania doraźnych problemów sprawdzonych i uznanych przez autorytety wskazywanych przez interesariuszy ze względu na ich ekonomiczne lub polityczne potrzeby ${ }^{27}$.

I dalej:

nastawienie na dostosowanie, na kształtowanie kompetencji pragmatycznych oraz zachowanie transmisyjnego paradygmatu wiedzy pewnej i ustalonej nie sprzyja twórczości naukowej, wychodzeniu poza wyznaczone formalnie pole aktywności poznawczej i edukacyjnej ${ }^{28}$.

${ }_{27}$ M. Czerepaniak-Walczak, Studia doktoranckie w systemie szkolnictwa wyższego i w społeczeństwie wiedzy: komu i do czego potrzebne sq studia doktoranckie na kierunku/w dyscyplinie Pedagogika, „Rocznik Pedagogiczny” 2013, t. 36, s. 76.

28 Ibidem, s. 78 . 
Dlatego trzeba zadać sobie pytanie „skoro nauka wymaga fantazji, wyobraźni, kreatywności myślenia, to dlaczego od naukowców (także tych stawiających pierwsze kroki w roli badacza) wymaga się, aby dobrze wkomponowali się w naukowy mainstream usankcjonowany instytucjonalnie?"29. Czy nie jest tak, że ograniczanie się tylko do bieżących zastosowań utylitarnych odziera naukę z możliwości rzeczywistego rozwoju? Godzi to w ideę humanizmu, ponieważ człowiek nie jest tylko istotą, która potrzebuje nowych technicznych wynalazków czy utylitarnych udogodnień. Jest on przede wszystkim istotą rozumną, poszukującą zrozumienia rzeczywistości ${ }^{30}$. Szczególnie problem ten dotyka przedstawicieli nauk humanistycznych, których Jerome Bruner lokuje między naukowcami a poetami. Ich rola polega bowiem z jednej strony na obiektywizowaniu świata i objaśnianiu go, z drugiej, jak pisze J. Bruner, na jego metaforyzowaniu, ponieważ zarówno poeci, jak i naukowcyhumaniści pełnią role mitotwórców współczesności ${ }^{11}$. Odwołując się do symboliki prawej i lewej ręki, Autor pokazuje, że nauka to sięganie po wiedzę prawą ręką (oddaje ona ład, porządek, obiektywizm, biegłość techniczną, rzemiosło), ale to lewa ręka symbolizuje hipotetyzowanie, fantazjowanie, pewien nieład i niepewność, które dynamizują uprawianie nauki i dają jej pełny smak $^{32}$. Metafora prawej i lewej ręki nie dotyczy tylko metodologii uprawiania nauki. Chodzi tu także o rozumienie przez badaczy swojego miejsca w świecie - między formalizmem i taktyką a wolnością i podejmowaniem ryzyka. Jak już wcześniej pisaliśmy, środowiska akademickie powinna cechować pewna swoboda stawiania pytań, możliwość kwestionowania zastanej rzeczywistości i problematyzowania pewnych kwestii ciągle na nowo. Czy jest to jednak możliwe w obliczu oczekiwań stawianych obecnie uniwersytetom? Nauki humanistyczne są w kryzysie, przestają bowiem być, jak zauważa Marek Konopczyński, motorem napędowym konstruktywnych zmian społecznych, rozpaczliwie poszukują zaś własnej tożsamości³. Z pewnością wiąże się to przynajmniej po części z dylematami, wobec których stają osoby te nauki uprawiające.

\section{Z. Król, Filozofia a nauki..., s. 68.}

Ibidem, s. 65-69.

J. Bruner, O poznaniu. Szkice na lewą rękę, przekł. E. Krasińska, Państwowy Instytut Wydawniczy, Warszawa 1971, s. 17.

Ibidem, s. 16.

M. Konopczyński, Etos nauki a współczesne polskie szkolnictwo wyższe. Refleksje pedagoga...., [w:] Innowacje w edukacji akademickiej. Szkolnictwo wyższe w procesie zmiany, J. Piekarski, D. Urbaniak-Zająć (red.), Wydawnictwo Uniwersytetu Łódzkiego, Łódź 2010, S. 205. 
Zatem współczesny naukowiec nie godząc się z rzeczywistością, w której jest zanurzony, musi odpowiedzieć sobie na pytania: czy dryfować z nurtem przemian (być niewolnikiem ekonomii punktów naukowych, biurokracji i realizacji efektów kształcenia KRK)? Czy przejawiać nieposłuszeństwo akademickie i płynąć pod prąd? Czy zacumować i stanąć w miejscu manifestując swoje nieposłuszeństwo? Wokół tych metafor mnożą się pytania: dokąd zaniesie nas prąd? Czy przetrwamy - wszak prąd ma ogromną siłę? Czy warto podejmować wysiłek płynięcia do źródła? Czym to źródło jest? Czy ma to w ogóle sens (wszak nie jest zgodne $\mathrm{z}$ „logiką" rzeki....?) Czy umiemy uargumentować takie działania? Jeśli zacumujemy, to po co? Co jest w tej podróży bezpieczną przystanią? Co kotwicą? Czy ci, co bezpiecznie zacumowali, dotrą kiedyś tam, gdzie innych niesie niespokojna fala?

Może warto szukać przejawów akademickiego nieposłuszeństwa wokół siebie i w nas.

\section{BIBLIOGRAFIA}

Arendt H., Myślenie, przekł. H. Buczyńska-Garewicz, Wydawnictwo Czytelnik, Warszawa 2002.

Barańska E., Moralność w polityce: rozważania w kontekście teorii politycznej Hannah Arendt, „Teki Komisji Politologii i Stosunków Międzynarodowych. - OL PAN” 20o8, s. 49.

Bruner J., O poznaniu. Szkice na lewą rękę, przekł. E. Krasińska, Państwowy Instytut Wydawniczy, Warszawa 1971.

Bylica U., Dąbrowski B., Od Gali do Kabaretu - programy satyryczne Letnich Szkół Młodych Pedagogów, [w:] O budowaniu kapitału ludzkiego i społecznego w środowisku naukowym. 2o-lecie Letniej Szkoły Młodych Pedagogów przy Komitecie Nauk Pedagogicznych PAN, E. Bochno, A. Korzeniecka-Bondar (red.), Wydawnictwo Uniwersytetu Marii Curie-Skłodowskiej, Lublin 2011.

Czerepaniak-Walczak M., Autonomia $w$ kolorze sepii $w$ inkrustowanej ramie KRK. O procedurach i treściach zmiany w edukacji akademickiej, [w:] Fabryki dyplomów czy universitas? O „nadwiślańskiej” wersji przemian w edukacji akademickiej, M. Czerepaniak-Walczak (red.), Oficyna Wydawnicza Impuls, Kraków 2013.

Czerepaniak-Walczak M., Studia doktoranckie $w$ systemie szkolnictwa wyższego $i$ w społeczeństwie wiedzy: komu i do czego potrzebne sq studia doktoranckie na kierunku/w dyscyplinie Pedagogika, „Rocznik Pedagogiczny” 2013, t. 36.

Czyżewski M., Dyskursy tożsamościowe w nauce i życiu społecznym: odmiany, własności, funkcje, [w:] Tożsamość, nowoczesność, stereotypy. Księga Jubileuszowa poświęcona Profesorowi Zbigniewowi Bokszańskiemu, R. Dopierała, K. Kaźmierska (red.), Nomos, Kraków 2012.

Dudzikowa M., Poczucie humoru nauczycieli wocenie uczniów, [w:] Problemy współczesnej pedeutologii. Teoria-praktyka-perspektywy, D. Ekiert-Oldroyd (red.), Wydawnictwo Uniwersytetu Śląskiego, Katowice 2003.

Dudzikowa M., Niekomfortowe położenie instytucji uniwersytetu w kłopotliwym kontekście. Esej w trosce o rozwój (nie tylko) kapitału społecznego, [w:] M. Dudzikowa, R. Wawrzyniak-Beszterda, S. Jaskulska, M. Marciniak, E. Bochno, I. Bochno, K. Knasiecka-Falbierska, Oblicza kapitału społecznego uniwersytetu. Diagnozy-interpretacje-konteksty, Oficyna Wydawnicza Impuls, Kraków 2013.

http://sliwerski-pedagog.blogspot.com. 
Giroux H. A., Naga pedagogia i przekleństwo neoliberalizmu: przemyśleć edukację wyższa jako praktykę wolności, przekł. P. Zamojski, [w:] Edukacja i sfera publiczna. Idee i doświadczenia pedagogiki radykalnej, H. A. Giroux, L. Witkowski, Oficyna Wydawnicza Impuls, Kraków 2010, s. 289.

Jakubiak-Mirończuk A., Model tworzenia prawa w Polsce po reformie Better Regulation a idea demokracji deliberatywnej, „Zeszyty Naukowe Zakładu Europeistyki Wyższej Szkoły Informatyki i Zarządzania w Rzeszowie" 2009, nr 3.

Konopczyński M., Etos nauki a współczesne polskie szkolnictwo wyższe. Refleksje pedagoga..., [w:] Innowacje w edukacji akademickiej. Szkolnictwo wyższe w procesie zmiany, J. Piekarski, D. Urbaniak-Zając (red.), Wydawnictwo Uniwersytetu Łódzkiego, Łódź 2010.

Król Z., Filozofia a nauki ścisłe, „Filozofia i Nauka. Studia Filozoficzne i Interdyscyplinarne” 2014, t. 2.

Matynia E., Negocjujmy rewolucje: uwagi o demokracji performatywnej, „Kultura i Edukacja” 2009, $\mathrm{nr} 2(71)$.

Matynia E., Demokracja performatywna, „Alternativa Dictionery”, http://alternativa.org.pl/ dictionary/? $\mathrm{p}=104$.

Rawls J., Teoria sprawiedliwości, przekł. M. Panufnik, J. Pasek, A. Romaniuk, Wydawnictwo Naukowe PWN, Warszawa 1994.

Reykowski J., Procesy grupowe a rozwiązywanie antagonistycznych konfliktów: Czy idea demokracji deliberatywnej może mieć swój psychologiczny sens?, „Psychologia Społeczna” 2007, t. 2.

Szutta A., Przemoc a obywatelskie nieposłuszeństwo, „Analiza i Egzystencja” 2013, nr 22.

Szymborska W., Wiersze wybrane, Wydawnictwo a5, Kraków 2004.

Wasilewski J., Podstawy demokracji deliberatywnej, [w:] Konflikt i porozumienie. Psychologiczne podstawy demokracji deliberatywnej, J. Reykowski (red.), Wydawnictwo Szkoły Wyższej Psychologii Społecznej „Academica”, Warszawa 2007.

\section{SUMMARY}

\section{"Let's run away ...": a paper on academic disobedience}

The purpose of the text is to show the problems associated with the process of changes in higher education, in particular parametrization that takes the academic achievements of scholars as its object. Among the reactions to that situation in academic circles, there is the attitude similar to "civil disobedience". Examples, which are given by the authors, relate to actions that express disagreement with reality and search for ways to change it. In accordance with the conclusions of the text, this attitude is the privilege and duty of scientists.

KEYWORDS: higher education, parametrization, civil disobedience. 

Pod patronatem

Komitetu Nauk Pedagogicznych PAN ukazują się:

"Rocznik Pedagogiczny"

"Studia Pedagogiczne"

"Studia z Teorii Wychowania"

"Problemy Wczesnej Edukacji"

„Biuletyn Historii Wychowania”

„Resocjalizacja Polska”

„Pedagogika Społeczna" 